Article

\title{
Project-Based Learning through Information and Communications Technology and the Curricular Inclusion of Social Problems Relevant to the Initial Training of Infant School Teachers
}

\author{
Delfín Ortega-Sánchez ${ }^{1, *(1)}$ and Alfredo Jiménez-Eguizábal ${ }^{2}$ (D) \\ 1 Department of Specific Didactics, Faculty of Education, University of Burgos, 09001 Burgos, Spain \\ 2 Department of Educational Sciences, Faculty of Education, University of Burgos, 09001 Burgos, Spain; \\ ajea@ubu.es \\ * Correspondence: dosanchez@ubu.es; Tel.: +34-947-111-832
}

Received: 7 October 2019; Accepted: 11 November 2019; Published: 13 November 2019

check for updates

\begin{abstract}
Project-based learning (PBL) is considered to be one of the most highly valued methods in the development and acquisition of competencies at all educational levels. From an interdisciplinary and collaborative focus, pupils acquire knowledge and skills through investigative tasks, with a view to responding to a problem or challenge, in the form of a final product. The methodological implementation of PBL in specific teacher-training contexts is especially useful for curricular inclusion and the didactic treatment of relevant contemporary social problems and socially alive questions. In this investigation, the assessment of the perceived learning of a group of infant-education teacher trainees $(n=59)$, following a teacher-training program on social problems, is analyzed. The program is designed on the basis of the principal methodologies of PBL and the operational integration of information and communications technology (ICT) (WebQuests). The study begins with the pre-experimental quantitative designs of a cross-cutting prospective nature with a control group. The results provide information on the special didactic potential of active methodologies, including PBL, for the creative development of thought processes and the acquisition of social competencies and good citizenship in relation to social problems on interdisciplinary curricular projects for infant education. Likewise, it is evident that PBL methodology through ICT facilitates the acquisition of technological competencies, linked to the development of social and communicative competencies, as well as cooperative-collaborative work.
\end{abstract}

Keywords: project-based learning; social problems; infant education; teacher training; WebQuests

\section{Introduction}

Assessed as one of the active student-centered methodologies [1] and the acquisition of competencies, project-based learning (PBL) encourages higher levels of responsibility from pupils and students, who will have to manage their projects and problem-solving in work groups [2]. This methodology begins with constructivist principles, according to which the pupil builds knowledge through personal experience [3]. The learning results arise from a problem-solving oriented process, the end-purpose of learning, proposed at the outset when this methodology is implemented. From an interdisciplinary and collaborative approach, the students acquire knowledge and skills through investigative tasks, with a view to providing a response to the problem or challenge before them in the form of a final product [4-6].

Despite the unequal application of those methodological principles in higher education [7], their general guidelines consider the use of problems for knowledge construction, self-directed learning, 
student-centered teaching, group activity of the students, and the acceptance by the teacher of the role of animator rather than transmitter [8]. This methodological model seeks to align different curricular and educational elements in a coherent and integrated manner, such as competencies and objectives, the teaching design of the project, evaluation, materials, and student expectations $[9,10]$. The projects upon which the methodology is based follow PBL principles, understood as a model of teaching and learning in which "the students, actively and with a very clear personal intention, investigate their environment, form ideas and concepts around it, try to understand it, form opinions of it and act upon it" [11] (p. 46).

Among the specific PBL proposals in higher education, the following may be mentioned [12] (pp. 94-95): development of skills for problem-solving, both in the acquisition and the application of knowledge in different situations; development of critical thought, and the capability to analyze and to resolve complex real-world problems; development of skills for research, evaluation, and the use of appropriate learning resources; development of skills, values, and attitudes for collaborative work in teams and small groups; and, the development of skills for independent, self-directed, and permanent learning.

One of the strategies that best integrates the methodological principles of PBL is WebQuest (WQ). It is also the most useful in the development and acquisition of social and communicative competencies, critical and creative thought, and digital-teaching competencies [13]. Its designer, Bernie Dodge, describes it as an investigative activity in which the information with which the students interact arises totally or partially from Internet resources [14]. It could be affirmed that it is a guided learning unit, which consists of the development of varied sorts of tasks (investigation, analysis, etc.), completed on the basis of consulting websites previously selected by the teacher [15], or a guided learning strategy by discovery that is developed by students, using the resources of the World Wide Web, which integrates "the principles of constructivist learning, project-based learning teaching and web navigation to develop the curriculum with a group of students in an ordinary classroom [16].

WQ proposes a feasible, significant, and attractive task for students from a problematized proposal and an activity-based process, directed toward information processing (analysis, synthesis, creation, evaluation, etc.) for its solution [17]. Its design and application should be capable of promoting the development of cognitive skills of a higher order, transforming information into knowledge in a cooperative-collaborative manner. According to Dodge, one possible taxonomy of tasks contemplates activities relating to self-knowledge, science, judgement, design, mystery, analytics, compilation, and consensus, among others.

The selection of web resources by the teacher saves time that would otherwise be invested in their localization by the pupils, so as to prioritize the use, treatment, processing, and subsequent transformation of the information, after following up an inquiry/investigation process directed at developing critical thought, decision-making, and creativity, which are defining elements of PBL.

The WQ strategy offers multiple advantages for a functional integration of ICT in the infant-education classroom, and for the development of social competencies and learning-to-learn, cooperative-collaborative work and student creativity. In that sense, the implementation of WQ in work plans based on PBL is especially valid for the didactic treatment and curricular inclusion of relevant social problems and socially alive questions in infant and primary education [13,18]. This inclusion and didactic treatment of social problems from the early educational stages constitutes one of the most recognized teaching and research concerns in the scientific field of geographical, historical, and social education $[19,20]$. The acquisition of social and citizen competences, based on the development of critical and creative social-thinking skills, implies the approximation and understanding of the complexity of social reality for participation and intervention, in a critical and responsible way, in social and environmental problems.

There are numerous studies that show the advantages of integrating ICT for learning social, artistic-creative, and technological skills in early childhood education [21,22], as well as in training and teachers' professional development of this educational level [23-28]. Despite the known educational 
value of the WQ and its usefulness in the operational and effective integration of ICT in education, this strategy, located in certain teaching-learning models, such as the TPACK (Technological Pedagogical Content Knowledge) model, continues to generate interest in higher education, and in the development and acquisition of the digital competence of the future teachers [29], in particular, in the training for the disciplinary field of social sciences (geography and history) $[18,30]$.

From this scientific field, the 2016 International Declaration on Geographical Education highlights the relevance of technologies in improving geographic education for sustainable development, stating that those responsible for teaching geography need the best critical knowledge for the use of new technologies and problem-based learning about relevant social issues and education of the future [31,32]. However, we agree with Agut, Ull, and Minguet [33] to identify the absence of specific curricular contents and competencies aimed at sustainable development in early childhood education, as well as its teacher-training deficiencies.

From this methodological perspective, the curricular inclusion and the didactic treatment of social problems [34-37] are necessarily directed toward the initiation of the students in democratic participation, the development of social thought [38], and the generation of a social conscience in the teaching and learning of social sciences. In that sense, the acquisition of methodological and professional competencies that constitute education in and for democratic citizenship is necessary [39]. Within the framework of education for sustainability and, therefore, of the dimensional integration of sustainable development-social, cultural, economic, and environmental一the importance of this initiation lies in the need for early education for citizen participation, including the values of justice, tolerance, inclusion, solidarity, and cooperation [40-43].

Social problems, controversial topics, and socially alive questions are therefore presented as indispensable elements for the integral development of civic- and citizenship-related competencies [44], through their relations with the modeling of social thought $[45,46]$. The conversion of the social conflict or problem into content offers an excellent educational opportunity $[47,48]$ for the acquisition of learning that is truly based on competencies with which to approach, in a responsible and committed manner, contemporary social problems [19].

According to the United Nations Educational, Scientific, and Cultural Organization (UNESCO), sustainable development seeks to find a means to solve today's social and environmental problems and learn to live sustainably. Both social and environmental problems, understood as human problems of a social nature, constitute the explanatory core of education for sustainable development and demonstrate their relevance in the field of social studies and geographic education, from the earliest educational stages. According to Tonucci, "the child is a sensitive environmental indicator, and when the child is well and can walk the streets of the city, it will mean that the city will have resumed its natural function as a place of shared, cooperative, and solidarity experiences. This is a correct way to propose sustainable development" [49] (p. 78). From this perspective, the social-science-teacher training plans should respond to the conceptual interrelation between sustainable development and participatory citizenship.

Two decades have passed since the Council of Europe included, within the framework of the well-known Lisbon Strategy, the promotion of the concept of active citizenship and the learning of values and democratic participation as educational objectives. To speak of education for citizen participation or for the exercise of active citizenship implies reflecting on the way of teaching to intervene, from commitment and responsibility, in relevant social problems or controversial issues. Despite the progress made, the design of educational programs and practices specifically aimed at treating social and environmental problems, as well as community intervention from the perspective of active citizenship [41,50,51], continues to be necessary.

Understanding the teaching of social and human science disciplines as one of the priority curricular spaces for the promotion of social values and the commitment to a global democratic citizenship, education for sustainable development is presented as one of its fundamental axes. Precisely, the UNESCO World Conference for Sustainable Development, held in Nagoya (Japan) in 2014, recalled the 
necessary conceptual integration between education for development and global citizenship education, in order to respond to the social problems [52].

In this context, the present research analyzes the evaluations that relate to the perceived learning of a group of infant-education trainee teachers $(n=59)$ in the context of the methodological implementation of PBL for the curricular inclusion and treatment of social problems through ICT and, in particular, through WQ teaching designs. The following hypotheses are proposed:

Hypothesis 1 (H1): The students enrolled in the experimental group will perceive the existence of close didactic relations between the methodological implementation of $P B L$ and the development of creative thought and the necessary social competencies for the didactic treatment of relevant social problems and socially alive questions.

Hypothesis 2 (H2): The evaluations of the students enrolled in the experimental group, who follow the teaching program on ICT and social problems, will present higher scores than those of the control group for the evaluation of the methodological implementation of PBL in the teaching and learning of social sciences and in their initial training.

Hypothesis 3 (H3): The differences between the evaluations returned by the students in the experimental group will be statistically significant with regard to the evaluations returned by the control group.

Hypothesis 4 (H4): The follow-up of the teaching program will show high size-effects between the evaluations on the PBL - -ICT (project-based learning on social problems through ICT) scale produced by the experimental group and by the control group.

\section{Method}

\subsection{Participants}

The sample comprised a total of 59 students (women: $f=49 ; 83.1 \%$; men: $f=10 ; 16.9 \%$ ), enrolled in the third year of the Degree in Infant Education taught at the University of Burgos. The average age of the students was 21.20 years $(S D=2.27)$.

Their selection was based on intentional criteria, so that the characteristics of the participants would be adapted to the objectives of the investigation: enrolled on the study module ICT in the teaching of Social Sciences, an optional third-year module (experimental group) and, alternatively, enrolled on an optional module that is part of the same course and semester of the qualification (control group).

\subsection{Instrument}

The instrument of data collection consisted of a twelve-item questionnaire, designed ad hoc, with a 5-point Likert-type scale, where 1 was totally in disagreement and 5 was totally in agreement; and of two (nominal) categoric measurement items (sex and group). The preparation of the Project-based learning on social problems through ICT (PBLt-ICT) began with the review of scientific literature and, in particular, with the work of Ortega-Sánchez [13,53], and Ortega-Sánchez and Gómez-Trigueros [18].

Cronbach's alpha was calculated to determine the reliability and the internal consistency of the results and, the coefficient of composite reliability or omega coefficient, in view of the ordinal nature of the variables of the Likert scale that was applied. The results of both tests returned satisfactory indices $(\alpha=0.908 ; \omega=0.936)$.

A PCA exploratory factor analysis and a varimax rotation were performed to test the validity of the construct and the goodness of fit of the data. The type of factor rotation that was employed applied the Kaiser criterion to eigenvalues greater than 1 . The model identifies levels of correlation and the theoretical relation between the variables under study, to reduce their number and to summarize the data in accordance with the objective of the study.

Prior to the analysis, we examined the correlation/covariance matrix between the variables, with the aim of establishing the matrix factorization possibilities, through the application of Bartlett's 
sphericity test and the Kaiser, Meyer, and Olkin (KMO) measure of sampling adequacy. The results of the KMO test $(0.771)$ and the sphericity test $\left(\chi^{2}(45)=496.199 ; p<0.000\right)$ indicated the adequacy of the matrix to be factorized. The exploratory factor analysis identified three factors that explained $80.56 \%$ of the total variance. Loads lower than a value of 0.4 were omitted for the validation of the scale (Table 1 ).

Table 1. Matrix of factor loads of the project-based learning through information and communications technology $\left(\mathrm{PBL}_{\mathrm{t}}-\mathrm{ICT}\right)$ scale.

\begin{tabular}{|c|c|c|c|c|}
\hline & \multirow{2}{*}{ PBL $_{t}$-ICT Scale } & \multicolumn{3}{|c|}{ Component } \\
\hline & & 1 & 2 & 3 \\
\hline 1 & $\begin{array}{l}\text { PBL facilitates the development and the acquisition of social competencies around } \\
\text { social problems ranging from cooperation to collaboration. }\end{array}$ & 0.840 & 0.442 & \\
\hline 2 & $\begin{array}{l}\text { PBL facilitates the development and the acquisition of communicative competencies } \\
\text { ranging from cooperation to collaboration. }\end{array}$ & 0.831 & & 0.438 \\
\hline 3 & $\begin{array}{l}\text { PBL drives the development of personal competencies (empathy) ranging from } \\
\text { cooperation to cooperation. }\end{array}$ & 0.818 & & \\
\hline 4 & $\begin{array}{l}\text { PBL and its articulation through ICT (WQ) facilitates the development and the } \\
\text { acquisition of technological competencies ranging from cooperation to collaboration. }\end{array}$ & 0.703 & & 0.409 \\
\hline 5 & $\begin{array}{l}\text { PBL favors the development and the acquisition of higher-order cognitive skills in a } \\
\text { cooperative-collaborative way. }\end{array}$ & 0.520 & 0.508 & \\
\hline 6 & PBL promotes decision-making and solutions to social problems (creative thought). & & 0.876 & \\
\hline 7 & PBL stimulates the development of critical thought upon relevant social problems. & & 0.844 & \\
\hline 8 & $\begin{array}{l}\text { PBL is useful in curricular inclusion and the didactic treatment of social problems } \\
\text { relevant to infant education. }\end{array}$ & & 0.622 & 0.506 \\
\hline 9 & $\begin{array}{l}\text { The operational integration of the ICT (WQ) facilitates the transformation of digital } \\
\text { information handled by students into social knowledge, on the basis of the } \\
\text { methodological implementation of the ABP. }\end{array}$ & & & 0.922 \\
\hline 10 & $\begin{array}{l}\text { WQ permits a truly operational integration of the ICT in the teaching of social } \\
\text { sciences, on the basis of the methodological implementation of PBL. }\end{array}$ & 0.487 & & 0.683 \\
\hline
\end{tabular}

The results confirmed the dimensional correspondence of the instrument with the three following factors:

Factor 1. PBL, competencies and cooperative-collaborative work (5 items): the items linked with this dimension highlight the contribution of the principle methodologies of the PBL to the development and the acquisition of key (personal, social, communicative, and technological) competencies and cognitive skills of a higher order, through the cooperation and the collaboration of the students.

Factor 2. PBL, social problems, and critical and creative thought (3 items): the items linked with this dimension are oriented toward the potential didactic contributions of the PBL methodology for curricular inclusion and the didactic treatment of relevant social problems and socially alive questions in the teaching and learning of social sciences in infant education. This inclusion begins with the development of (critical and creative) social thought for analysis and participation in the social context of the student.

Factor 3. ICT (WQ), social knowledge and PBL (2 items): the two last items concretize the use of WQ as a strategy for the functional and operational integration of ICT in the teaching and the learning of the social context, and in the construction of social knowledge through the methodological principles of PBL.

\subsection{Design and Procedure}

The investigation follows the methodological principles of quantitative investigation and begins with the pre-experimental designs with a prospective cross-sectional control group $[54,55]$.

The questionnaire was administered during the final week of the ICT study module on the social sciences course during two academic years. After the explanation of the purpose of the investigation, 
the participants were reminded that any personal data would remain anonymous and would be treated as confidential.

As an add-on strategy [56] to the study plan of the Degree in Infant Education (Infant School Teacher) and a project approach by disciplines, the trainee teacher responsible for the study module presented the problematic social issues during the first teaching sessions, with which they would have to work for 51 practice hours. Each issue, centered on real life, is described as a structural axis upon which to define the problem around the pluralist construction of cultural identities, social inequality (among which, those of gender), and economics, sustainability, poverty, armed conflict, and the defense of Human Rights. Through the design of different study cases, small groups of students, guided by their own experience, had to discuss the curricular viability of their proposals, challenging the educational stage of infant education and the action plan, including the digital selection of materials and resources, in order to approach the social problem or socially alive question chosen on the basis of a critical social approach [57]. Once the teaching design and its challenging question had been decided and agreed with the teacher, the students sequenced the digital development of the project on the basis of the preparation of each one of the sections that comprise the WQ, adjusted to the methodological principles of the PBL: introduction, task, process, evaluation, resources, evaluation, and self-evaluation of its future staff. The didactic sequences of the ABP were matched, therefore, with the organizational phases of the WQ design. The development of group projects could be done in PowerPoint and, preferably, on specific platforms (BookWidgets. Interactive Learning/https://www.bookwidgets.com) (Figures 1 and 2).

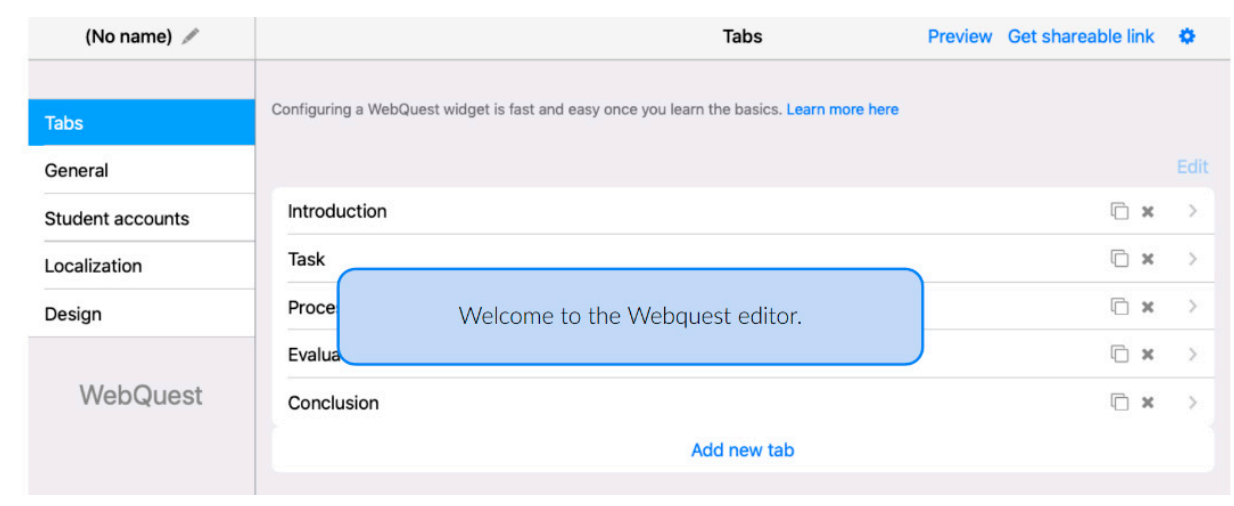

Figure 1. WebQuest editor. Initial screen.

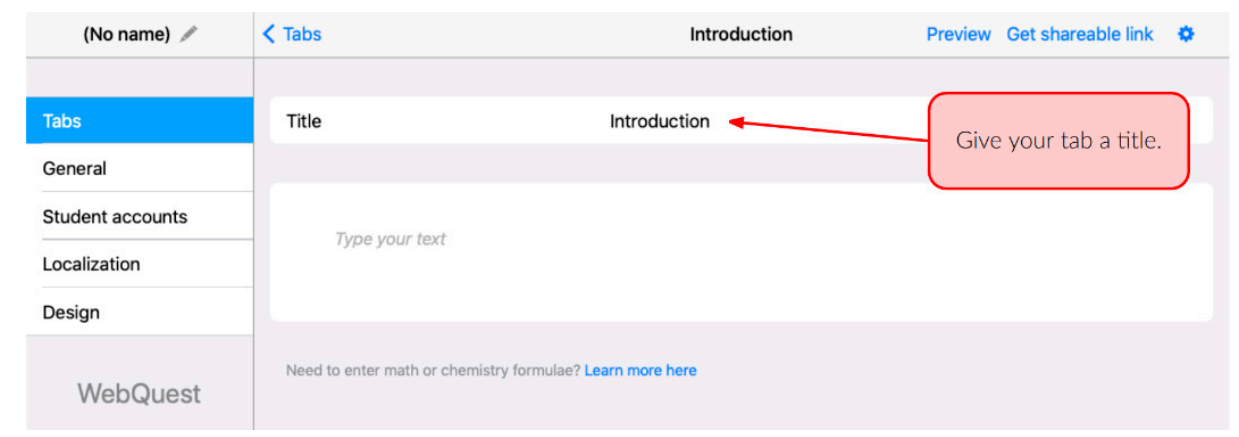

Figure 2. WebQuest editor. Data tab on the first page.

In the conceptual framework of the WQ, the presentation of the social problems selected by the trainee teachers should be expressed as a challenge for the pupils of infant education. Likewise, the trainee teachers should consider the development of cognitive skills of a higher order in their problem-solving designs task (final product of the process), among which, those corresponding to critical and creative thought and to those of investigation. Finally, the evaluation included in the WQ 
projects would have to value the scope of those cognitive skills present in the design of the activities of the process and, in an integrated manner, in the final products that are suggested. Equally, the projects should favor cooperative-collaborative construction of social knowledge among future pupils of infant education.

The control group received the programmed training content from a traditional approach, based on normative principles of the Spanish Social Sciences curriculum for Early Childhood Education. Consequently, there was no didactic treatment and curricular inclusion of social and environmental problems (absent, specifically, in the official curriculum) through information and communications technology. In any case, in both groups, the students adequately achieved the basic objectives and professional competences included in their teaching guides.

\subsection{Data Analysis}

Aware of the asymmetrical distribution of the variables of study, we completed a descriptive analysis (medians, SD, and variance) of the total obtained and an inferential analysis (coefficients of correlation rho of Spearman by factors and scale, and the Man-Whitney $U$-test), with the objective of testing the existence of statistically significant differences in each group (control and experimental).

With a view to testing the size of the difference between the assessments of the experimental group and the control group, we calculated the effect size [58] and interpreted the results in accordance with Cohen's criteria [59].

We used the statistical package SPSS v.24 for the treatment and the analysis of quantitative data.

\section{Results}

The students enrolled in the control group and in the experimental group expressed their generalized agreement with the didactic capability of the PBL methodology for the development and the acquisition of social and communicative competencies, and the promotion of higher-order cognitive skills through cooperative and collaborative work in the teaching-learning of the social sciences (Table 2).

Table 2. Descriptive statistics by variable and by group on the $\mathrm{PBL}_{\mathrm{t}}$-ICT scale.

\begin{tabular}{ccccccc}
\hline & \multicolumn{3}{c}{ Control Group $(n=30)$} & \multicolumn{3}{c}{ Experimental Group $(n=29)$} \\
\hline Item & $\boldsymbol{M}_{\boldsymbol{e}}$ & $\boldsymbol{S D}$ & Var. & $\boldsymbol{M}_{\boldsymbol{e}}$ & $\boldsymbol{S D}$ & Var. \\
\hline 1 & 4 & 0.490 & 0.240 & 4 & 0.509 & 0.259 \\
2 & 4 & 0.466 & 0.217 & 5 & 0.258 & 0.067 \\
3 & 4 & 0.679 & 0.461 & 5 & 0.384 & 0.148 \\
4 & 3 & 0.507 & 0.257 & 4 & 0.509 & 0.259 \\
5 & 4 & 0.379 & 0.144 & 5 & 0.412 & 0.170 \\
6 & 3 & 0.834 & 0.695 & 4 & 0.484 & 0.234 \\
7 & 3 & 0.714 & 0.510 & 4 & 0.471 & 0.222 \\
8 & 3 & 0.183 & 0.033 & 4 & 0.509 & 0.259 \\
9 & 3 & 0.868 & 0.754 & 4 & 0.471 & 0.222 \\
10 & 4 & 0.490 & 0.240 & 4 & 0.509 & 0.259 \\
\hline
\end{tabular}

The assessments are especially prominent in the experimental group under items 2 (communicative competences), 3 (personal competences/empathy), and 5 (cognitive skills of a higher order), with averages of 5 (totally agree) and a low dispersion of the data $(<0.45)$. While that group expressed their satisfaction with the potential of PBL for the acquisition of technological competencies $\left(M_{e}(\exp\right.$.) $=4$, $S D=0.50)$, the students enrolled in the control group expressed doubts over that particular didactic advantage $\left(M_{e}\right.$ (con.) $\left.=3, S D=0.50\right)$.

The development of (critical and creative) social thought, and both the curricular inclusion and the didactic treatment of social problems through the implementation of the methodological principles of PBL were highly valued aspects by the experimental group 
$\left(M_{e}\right.$ (exp.) $\left.=4, S D<0.50\right)$. The control group, on the contrary, expressed its doubts in relation to those potential didactic advantages $\left(M_{e}\right.$ (exp.) $=3, S D \geq 0.18$ ), with a significant dispersion of the scores given to item 6 (creative thought) $(S D=0.83)$ and item $7(S D=0.71)$.

Finally, the students enrolled in the experimental group expressed their agreement with the contribution of this methodology to the construction of social knowledge and the operational and functional integration of ICT (WQ) in the social sciences classroom $\left(M_{e}(\exp )=4,. S D<0.50\right)$. The control group, in turn, expressed agreement with the functional integration of ICT and PBL in the teaching of social sciences $\left(M_{e}\right.$ (con.) $\left.=4, S D=0.49\right)$, but expressed doubts, with a significant dispersal of its responses, over its contributions to the construction of social knowledge and the implementation of the principles of PBL $\left(M_{e}\right.$ (con.) $\left.=3, S D=0.86\right)$.

With the exception of the absence of any correlation between the didactic possibilities of ICT (WQ) in the construction of social knowledge on the basis of PBL, and the potential of that active methodology for the development and the acquisition of social competencies through tasks relating to social issues, all the variables that formed the scale, on the whole, recorded moderate degrees of agreement. High levels of dependency stand out, nevertheless, between the advantages of the implementation of PBL and the development of personal (empathy) and communicative competencies; between the didactic contributions of PBL and ICT (WQ) to the acquisition of technological competencies, and the development of communicative and social competencies through tasks relating to social issues; between the contributions of this methodology to the development of critical thought and the solutions to social problems (creative thought); between its methodological possibilities for curricular inclusion and the didactic treatment of social issues, and the development of creative thought; and, finally, the dependency between the operational integration of ICT (WQ) for the construction of social knowledge and the acquisition of technological competencies through the methodological principles of PBL (Table 3). Very notable relations of dependency are evident between the development and the acquisition of critical thought and creative thought through PBL, and the strong linkage of PBL with curricular inclusion and the didactic treatment of relevant social problems in infant education.

Table 3. Correlation coefficients by variable and levels of meaning (experimental and control groups).

\begin{tabular}{|c|c|c|c|c|c|c|c|c|c|c|}
\hline & 1 & 2 & 3 & 4 & 5 & 6 & 7 & 8 & 9 & 10 \\
\hline 1 & 1 & & & & & & & & & \\
\hline 2 & $0.648^{* *}$ & 1 & & & & & & & & \\
\hline 3 & 0.673 ** & $0.705^{* *}$ & 1 & & & & & & & \\
\hline 4 & $0.738^{* *}$ & $0.747^{* *}$ & $0.618^{* *}$ & 1 & & & & & & \\
\hline 5 & $0.606^{* *}$ & $0.551^{* *}$ & $0.524^{* *}$ & $0.426^{* *}$ & 1 & & & & & \\
\hline 6 & $0.485^{* *}$ & 0.304 * & $0.346^{* *}$ & $0.568^{* *}$ & $0.511^{* *}$ & 1 & & & & \\
\hline 7 & $0.679 * *$ & $0.410^{* *}$ & $0.486^{* *}$ & $0.586^{* *}$ & $0.534^{* *}$ & $0.704^{* *}$ & 1 & & & \\
\hline 8 & $0.589 * *$ & 0.548 ** & 0.698 ** & 0.661 ** & $0.568^{* *}$ & $0.751 * *$ & $0.691 * *$ & 1 & & \\
\hline 9 & 0.165 & $0.462 * *$ & $0.476^{* *}$ & $0.376^{* *}$ & 0.400 ** & 0.506 ** & $0.333 *$ & $0.664 * *$ & 1 & \\
\hline 10 & $0.620 * *$ & 0.648 ** & 0.449 ** & $0.775^{* *}$ & 0.401 ** & 0.603 ** & 0.430 ** & $0.589 * *$ & 0.553 ** & 1 \\
\hline
\end{tabular}

The intensity of the correlations between the variables by group showed high correlations, for the experimental group, between the contributions of PBL to the development of creative thought and the acquisition of social competencies through the didactic treatment of social issues $(\varrho=0.75$, $p=0.0001)\left(\mathrm{H}_{1}\right)$; between the contribution of PBL through ICT (WQ) to the acquisition of technological competencies and social competencies $(\varrho=0.72, p=0.0001)$; and between the possibilities of operational integration of the ICT (WQ), through PBL, in the construction of social knowledge and in the acquisition of social $(\varrho=0.86, p=0.0001)$ and technological competencies $(\varrho=0.86, p=0.0001)$, and in the development of creative thought for solving social problems $(\varrho=0.75, p=0.0001)$.

These results were achieved with a moderate degree of correlation between factors 1 and $3(\varrho=0.57$, $p \leq 0.01$ ) (Table 4). 
Table 4. Factor correlation coefficients and significance levels (experimental group).

\begin{tabular}{lcccc}
\hline & & Factor 1 & Factor 2 & Factor 3 \\
\hline Factor 1 & PBL, competencies, and cooperative-collaborative work. & 1 & & \\
Factor 2 & PBL, social issues, and critical and creative thought. & 0.331 & 1 & \\
Factor 3 & ICT (WQ), social knowledge, and PBL. & $0.574^{* *}$ & 0.334 & 1 \\
\hline & Notes: ${ }^{* *} p \leq 0.01$. & &
\end{tabular}

In the control group, in contrast, a very high correlation was obtained between the contributions of PBL to the development of personal competencies (empathy) and the acquisition of social competencies $(\varrho=0.92, p=0.0001)$. Likewise, there were high correlations between the acquisition of technological competencies through PBL and ICT (WQ) and the development and the acquisition of communicative competencies $(\varrho=0.70, p=0.0001)$. High levels of correlation were also recorded between the operational integration of ITC (WQ) for the construction of social knowledge through PBL in the teaching of social sciences $(\varrho=0.78, p=0.0001)$ and in the development of critical thought through the didactic treatment of relevant social issues $(\varrho=0.70, p=0.0001)$.

The assessments given by the experimental group exceeded, by one degree, the assessments in the control group in each of the factors of the scale $\left(\mathrm{H}_{3}\right)$. Those intergroup differences were statistically significant in all the factors that constituted the scale $\left(\mathrm{H}_{2}\right)$ (Table 5).

Table 5. Factor comparison by groups.

\begin{tabular}{lcccccccc}
\hline & \multicolumn{7}{c}{ Control $(n=30)$} & Experimental $(n=29)$ \\
\cline { 2 - 9 } & $\boldsymbol{M}_{\boldsymbol{e}}$ & $\boldsymbol{D T}$ & Var. & $\boldsymbol{M}_{\boldsymbol{e}}$ & $\boldsymbol{D T}$ & Var. & $\boldsymbol{U}$ & $\boldsymbol{r}$ \\
\hline Factor 1 & 4.00 & 0.551 & 0.303 & 5.00 & 0.384 & 0.148 & $84.0^{* * * *}$ & 0.75 \\
Factor 2 & 3.00 & 0.521 & 0.271 & 4.00 & 0.484 & 0.234 & $9.5^{* * *}$ & 0.87 \\
Factor 3 & 3.50 & 0.645 & 0.416 & 4.50 & 0.246 & 0.060 & $42.0^{* * *}$ & 0.81 \\
Scale & 3.50 & 0.410 & 0.168 & 4.50 & 0.450 & 0.203 & $60.0^{* * *}$ & 0.76 \\
\hline \multicolumn{10}{c}{ Notes: ${ }^{* * *} p<0.001}$.
\end{tabular}

The magnitude of these differences yielded high size-effects for the first $(r=0.75)$, the second $(r>0.80)$, and the third factor. Likewise, a high size-effect between groups for the total of the scale was also found $(r=0.76)\left(\mathrm{H}_{4}\right)$.

\section{Discussion and Conclusions}

In accordance with the results from the experimental group, the implementation of active methodologies, particularly PBL, favors the development of creative thought [60] and social competencies through relevant social issues and socially alive questions, contemporaneous for pupils following infant education. This linkage between critical and creative thought, and the pedagogic principles of PBL, constitutes, in effect, one of the most characteristic defining relations of this active methodology [12]. The opinions of the students who followed the course of social issues and ICT, in effect, reflect a relation of moderate dependency between the functionality of ITC (WQ) and PBL in the transformation of digital contents in social knowledge, and in the development and acquisition of key competencies through cooperative-collaborative work. However, despite their high assessments, no relation is observed between the didactic potential of PBL for the specific curricular inclusion of relevant social issues and the development of social thought, and the factors linked to the acquisition of competencies and the operational integration of ICT in the teaching of social sciences.

The implementation of this methodology through ICT (WQ) facilitates the acquisition of technological and social competencies related to the issues that are approached. Evidence for the didactic advantages of the integration of ICT in active methodological proposals has been shown in investigations, such as those conducted by Chávez, Cantú, and Rodríguez [61]. The acquisition of technological competencies and digital-teaching competencies and their links with the development 
of social competencies, are among the factors that trainee teachers of infant education recognize best while following the training program.

PBL favors cooperative-collaborative work and the acquisition of communicative competencies [62] on the basis of interdisciplinary curricular projects. Along those lines, the conclusions reached in investigations on teaching experiences developed at the stage of infant education are significant [63-65].

PBL and the operational integration of ICT, and education and communication technologies (ECT) [66] favor the acquisition of the investigative competencies of future teachers of infant education. Their professional practices "must go beyond the consideration of technical tasks to be qualified as independent intellectual practice" [11] (p. 54), capable of generating projects for the description, analysis, and intervention in the social reality of students. Along those lines, "CPBL [collaborative project-based learning] simultaneously stimulates cognitive, motor, ethical, and affective aspects, enabling work with an active pedagogy. The students, as investigators, are turned into agents generating the knowledge that they learn" [60] (p. 169). From that perspective, the participants in the present investigation oriented their training activity toward the design of projects based on tasks and processes that would enable their future students to develop key competencies, social thought, and collaboration on the basis of guided solutions to the social issue that is selected [13].

The results of the projects that were presented confirmed that PBL in infant education "is a methodological resource that permits the development of capabilities at this psycho-evolutive stage, and [ ... ] that students can successfully develop in situations of daily life" [63] (p. 84). Those conclusions coincide with others reached by García-Varcálcel and Gómez-Pablos [67], which reflects the positive opinions expressed by fifth and sixth-year primary education pupils on PBL methodology.

The results are consistent with those obtained in recent research, which reveals the need to develop curricular guidelines and specific plans for the training teachers in early childhood education in ICT. Likewise, these studies emphasize the active and creative use of technologies [68] to improve the digital competence of future teachers [26]. These results offer suggestions to overcome, at different levels, the obstacles identified by Magen-Nagar and Firstater [27] in the implementation of ICT in this educational stage: (1) recognition and integration of the pedagogical value of ICT in the educational philosophy of trainee teachers; (2) use of ICT as a resource for the development and implementation of alternative teaching strategies (project-based learning); and (3) use of digital technological resources for the promotion of social and citizen learning in education, for sustainable development.

The didactic consideration of social problems as curricular content and strategy will, in consequence, favor the development of social thought, reflection and analysis of social reality [69], decision-taking, and the proposal of solutions [70,71]. In that sense, assuming the importance of the assessment of the results obtained from didactic experiences in the educational training of the teachers, longitudinal studies are necessary in the generic analysis of the implementation of PBL and, in particular, the curricular inclusion of social issues in the teaching practice of primary and infant school teachers. The absence of social issues in the infant and primary education curricula will limit the approach of pupils to integral social content, to its utility for understanding the world, and to their possibilities of interpretation and response for the understanding of the world, and to their possibilities of interpretation and their responses to the complexity that characterizes it. In accordance with the perceptions of learning received by future teachers of infant education, the active methodology of PBL and the integration of ICT in the (social and cultural) environmental studies classroom affect the proposal of problems that are part of the student's reality. However, the application of a single quantitative instrument, before and after the teaching intervention, motivates to accept, with caution, the consistency of the results obtained in the present investigation. In future studies, it would be necessary to use qualitative research techniques and instruments capable of deepening and confirming, in a comprehensive manner, the effects of teacher programming.

Finally, we agree with the limitations indicated by other studies on similar educational experiences based on PBL, which include the need for additional work for its implementation, the need to extend long periods of time [72], and the need to specify new forms of competencies assessment [3]. 
The high level of autonomy granted to students in their learning process also leads to difficulties in the development of the teacher/tutor's role [73]. Furthermore, if this teaching and learning strategy integrates ICT, it will require greater teacher training in the three types of content contemplated in the TPACK model (technological knowledge, pedagogical knowledge, and content knowledge) [74].

Author Contributions: Conceptualization, D.O.-S.; methodology, D.O.-S.; software, D.O.-S.; validation, D.O.-S.; formal analysis, D.O.-S.; investigation, D.O.-S.; resources, D.O.-S. and A.J.-E.; data curation, D.O.-S.; writing-original draft preparation, D.O.-S.; writing—review and editing, D.O.-S. and A.J.-E.; supervision, D.O.-S. and A.J.-E.; funding acquisition, D.O.-S. and A.J.-E.

Funding: This research received no external funding.

Acknowledgments: This research was completed with the support of the Research Group of the University of Burgos Didáctica de la Historia y de las Ciencias Sociales (DHISO).

Conflicts of Interest: The authors declare no conflicts of interest.

\section{References}

1. Huber, G.L. Aprendizaje activo y metodologías educativas. Rev. Educ. 2008, n. extr., 59-81.

2. Prince, M.J.; Felder, M. Inductive teaching and learning methods: Definitions, comparisions and research bases. J. Eng. Educ. 2006, 95, 123-138. [CrossRef]

3. García, J.; Pérez, J.E. Aprendizaje basado en proyectos: Método para el diseño de actividades. TCyE 2018, 10, $37-63$.

4. Bilgin, I.; Karakuyu, Y.; Ay, Y. The effects of Project Based Learning on undergraduate students' achievement and self-efficacy beliefs towards science teaching. Eurasia J. Math. Sci. Technol. Educ. 2015, 11, 469-477.

5. Rekalde, I.; García, J. El aprendizaje basado en proyectos: Un constante desafío. Innov. Educ. 2015, 25, 219-234.

6. Savin-Baden, M. Challenging models and perspectives of problem-based learning. In Management of Change; de Graaff, E., Kolmos, A., Eds.; Sense Publishers: Rotterdam, The Netherlands; Taipei, Taiwan, 2007; pp. 9-29.

7. Kolmos, A. Problem- and project-based learning in a global perspective: Community bulding or certification? In Visions Challenges and Strategies; Krogh, L., Aarup, A., Eds.; Aalborg University Press: Copenhague, Denmark, 2013; pp. 47-66.

8. Kolmos, A. Changing the curriculum to problem-based and project-based learning. In Outcome-Based Science, Technology, Engineering, and Mathematics Education: Innovative Practices; Mohd-Yusof, K., Ahmad, N., Mohd, A., Kamilah, S., Yusof, S., Mohammad, Y., Eds.; IGI Global: Hershey, PA, USA, 2012; pp. 50-61.

9. Biggs, J. Teaching for Quality Learning at University, 2nd ed.; Open University Press: London, UK, 2003.

10. Kolmos, A. Estrategias para desarrollar currículos basados en la formulación de problemas y organizados en base a proyectos. Educar 2004, 33, 77-96. [CrossRef]

11. Bautista, J.M.; Espigares, M.J.; Hernández, R.M. Aprendizaje Basado en Proyectos (ABP) ante el reto de una nueva enseñanza de las Ciencias. Rev. Bras. Ensino Ciènc. Tecnol. 2017, 10, 43-60.

12. Morales, P. Aprendizaje basado en problemas (ABP) y habilidades de pensamiento crítico ¿una relación vinculante? Rev. Electrón. Interuniv. Form. Profr. 2018, 21, 91-108. [CrossRef]

13. Ortega-Sánchez, D. La Historia y las TIC en Educación Infantil. Íber Didáct. Cienc. Soc. Geogr. Hist. 2017, $87,66-71$.

14. Dodge, B.J. Some Thoughts about WebQuests. 1995. Available online: http://webquest.org/sdsu/about_ webquests.html (accessed on 13 September 2018).

15. Osset, J. WebQuest; Ministerio de Educación, Cultura y Deporte, Subdirección General de Documentación y Publicaciones: Madrid, Spain, 2013.

16. Area, M. Webquest. Una Estrategia de Aprendizaje por Descubrimiento Basada en el Uso de Internet. Quaderns Digitals. Monográfico Webquests. 2004, 32. Available online: http://www.quadernsdigitals.net (accessed on 25 November 2018).

17. Adell, J. Internet en el Aula: Las WebQuest. Rev. Electrón. Tecnol. Educ. 2004, 17. Available online: http://www.edutec.es/revista/index.php/edutece/article/view/530 (accessed on 5 February 2019). 
18. Ortega-Sánchez, D.; Gómez-Trigueros, I.M. Las WebQuests y los MOOCs en la enseñanza de las Ciencias Sociales y la formación del profesorado de Educación Primaria. Rev. Electrón. Interuniv. Form. Profr. 2017, 20, 205-220.

19. Ortega-Sánchez, D.; Pagès, J. Las representaciones sociales de los problemas contemporáneos en estudiantes de magisterio de Educación Primaria. Rev. Investig. Esc. 2017, 93, 1-15. [CrossRef]

20. Ortega-Sánchez, D.; Olmos, R. Los problemas sociales relevantes o las cuestiones socialmente vivas en la enseñanza de las ciencias sociales. In Contribuciones de Joan Pagès al Desarrollo de la Didáctica de las Ciencias Sociales, la Historia y la Geografía en Iberoamérica; Jara, M., Santisteban, A., Eds.; Universidad de Comahue-Universitat Autònoma de Barcelona: Cipolletti, Argentina, 2018; pp. 203-214.

21. Mertala, P. Digital technologies in early childhood education-A frame analysis of preservice teachers' perceptions. Early Child Dev. Care 2017, 189, 1228-1241. [CrossRef]

22. Huang, Y.; Li, H.; Fong, R. Using Augmented Reality in early art education: A case study in Hong Kong kindergarten. Early Child Dev. Care 2015, 186, 879-894. [CrossRef]

23. Kerckaert, S.; Vanderlinde, R.; van Braak, J. The role of ICT in early childhood education: Scale development and research on ICT use and influencing factors. Eur. Early Child. Educ. Res. J. 2015, 23, 183-199. [CrossRef]

24. Nikolopoulou, K.; Gialamas, V. ICT and play in preschool: Early childhood teachers' beliefs and confidence. Int. J. Early Years Educ. 2015, 23, 409-425. [CrossRef]

25. Dong, C.; Mertala, P. It is a tool, but not a 'must': Early childhood preservice teachers' perceptions of ICT and its affordances. Early Years 2019, 1-16. [CrossRef]

26. Dong, C. 'Young children nowadays are very smart in ICT'-Preschool teachers' perceptions of ICT use. Int. J. Early Years Educ. 2018, 1-14. [CrossRef]

27. Magen-Nagar, N.; Firstater, E. The Obstacles to ICT Implementation in the Kindergarten Environment: Kindergarten Teachers' Beliefs. J. Res. Child. Educ. 2019, 33, 165-179. [CrossRef]

28. Nuttall, J.; Edwards, S.; Mantilla, A.; Grieshaber, S.; Wood, E. The role of motive objects in early childhood teacher development concerning children's digital play and play-based learning in early childhood curricula. Prof. Dev. Educ. 2015, 41, 222-235. [CrossRef]

29. Flores-Lueg, C. Análisis de experiencias docentes con implementación de WebQuest en Educación Superior. Edutec Rev. Electrón. Tecnol. Educ. 2015. [CrossRef]

30. Miralles, P.; Gómez, C.; Arias, L. Social sciences teaching and information processing. An experience using WebQuests in primary education teacher training. RUSC Univ. Knowl. Soc. J. 2013, 10, 344-357. [CrossRef]

31. De Miguel, R. La producción científica reciente en didáctica de la geografía a través de las sociedades geográficas. Declaraciones, publicaciones y proyectos a nivel nacional e internacional. Doc. d'Anàl. Geogr. 2017, 63, 575-596. [CrossRef]

32. Granados, J. Un instrumento de análisis para la investigación del uso de las TIC-TAC en la enseñanza de la Geografía para el desarrollo sostenible. In Metodologías de Investigación en Didáctica de las Ciencias Sociales; Ávila, R., Rivero, M., Domínguez, P., Eds.; Institución Fernando el Católico-Asociación Universitaria de Profesorado de Didáctica de las Ciencias Sociales: Zaragoza, Spain, 2010; pp. 313-325.

33. Agut, M.; Ull, M.; Minguet, P. Education for sustainable development in early childhood education in Spain. Evolution, trends and proposals. Eur. Early Child. Educ. Res. J. 2013, 22, 213-228. [CrossRef]

34. Evans, R.W.; Saxe, D.W. Handbook on Teaching Social Issues; NCSS: Washington, DC, USA, 1996.

35. Hess, D.E. Controversies about controversial issues in democratic education. PS Political Sci. Politics 2004, 37, 257-261. [CrossRef]

36. Legardez, A. L'enseignement des questions sociales et historiques, socialement vives. Le Cartable de Clio 2003, 3, 245-253.

37. Santisteban, A. La investigación sobre el desarrollo de la competencia social y ciudadana para una participación crítica. In Educar para la Participación Ciudadana en la Enseñanza de las Ciencias Sociales; De Alba, N., García, F.F., Santisteban, A., Eds.; Asociación Universitaria de Profesorado de Didáctica de las Ciencias Sociales-Díada Editora: Seville, Spain, 2012; pp. 277-286.

38. Canal, M.; Costa, D.; Santisteban, A. El alumnado ante problemas sociales relevantes: ¿Cómo los interpreta? ¿Cómo piensa la participación? In Educar para la Participación Ciudadana en la Enseñanza de las Ciencias Sociales; De Alba, N., García, F.F., Santisteban, A., Eds.; Asociación Universitaria de Profesorado de Didáctica de las Ciencias Sociales-Díada Editora: Seville, Spain, 2012; pp. 527-535. 
39. Jiménez, M.D.; Moreno, C. Formar para enseñar en participación ciudadana. Una experiencia integradora. In Educar para la Participación Ciudadana en la Enseñanza de las Ciencias Sociales; De Alba, N., García, F.F., Santisteban, A., Eds.; Asociación Universitaria de Profesorado de Didáctica de las Ciencias Sociales-Díada Editora: Seville, Spain, 2012; pp. 511-519.

40. Bolívar, A. Educación para la Ciudadanía; Graó: Barcelona, Spain, 2007.

41. Bolívar, A. Educar democráticamente para una ciudadanía activa. Rev. Int. Educ. Justicia Soc. (RIEJS) 2016, 5, 69-87. [CrossRef]

42. Pagès, J.; Santisteban, A. La educación para la ciudadanía y la enseñanza de las ciencias sociales, la geografía y la historia. Íber Didáct. Cienc. Soc. Geogr. Hist. 2010, 64, 8-18.

43. Sánchez-Blanco, C. Learning about democracy at school: An action research project in early childhood education. Educ. Action Res. 2015, 23, 514-528. [CrossRef]

44. De Alba, N.; García, F.F.; Santisteban, A. Educar para la Participación Ciudadana en la Enseñanza de las Ciencias Sociales; Asociación Universitaria de Profesorado de Didáctica de las Ciencias Sociales-Díada Editora: Seville, Spain, 2012.

45. Pagès, J.; Santisteban, A. Les Qüestions Socialment Vives i L'ensenyament de les Ciències Socials; Universitat Autònoma de Barcelona: Barcelona, Spain, 2011.

46. Pagès, J.; Santisteban, A. Una mirada del pasado al futuro en la Didáctica de las Ciencias Sociales. In Una Mirada al Pasado y un Proyecto de Futuro. Investigación e Innovación en Didáctica de las Ciencias Sociales; Pagès, J., Santisteban, A., Eds.; Universitat Autònoma de Barcelona-Asociación Universitaria de Profesorado de Didáctica de las Ciencias Sociales: Barcelona, Spain, 2014; pp. 17-39.

47. Huddleston, $\mathrm{T}$. Teacher training in citizenship education: Training for a new subject or for a new kind of subject? J. Soc. Sci. Educ. 2005, 4, 50-63.

48. Santisteban, A. La formación del profesorado para hacer visible lo invisible. In Una Enseñanza de las Ciencias Sociales para el Futuro: Recursos para Trabajar la Invisibilidad de Personas, Lugares y Temáticas; Hernández, A.M., García, C.R., de la Montaña, J.L., Eds.; Universidad de Extremadura-Asociación Universitaria de Profesorado de Didáctica de las Ciencias Sociales: Cáceres, Spain, 2015; pp. 383-393.

49. Tonucci, F.; Bobbio, N. La Città dei Bambini; GLF Editori Laterza: Rome, Italy, 2005.

50. Jerome, L. Critical citizenship experiences? Working with trainee teachers to facilitate active citizenship in schools. Teach. Dev. 2006, 10, 313-329. [CrossRef]

51. Peterson, A.; Knowles, C. Active citizenship: A preliminary study into student teacher understandings. Educ. Res. 2009, 51, 39-59. [CrossRef]

52. UNESCO. Educación para la Ciudadanía Mundial. Temas y Objetivos de Aprendizaje; UNESCO: Paris, France, 2015.

53. Ortega-Sánchez, D. Las TIC y el desarrollo de competencias básicas en la enseñanza del conocimiento del medio social y cultural: Balance y propuesta para el grado en Maestro/a de Educación Primaria. In La Formación del Profesorado en Educación Infantil y Primaria: Retos y Propuestas; Alonso, J.I., Gómez, C.J., Eds.; Editum, Ediciones de la Universidad de Murcia: Murcia, Spain, 2014; pp. 305-312.

54. Hernández, R.; Fernández, C.; Baptista, M.P. Metodología de la Investigación; McGraw-Hill: México, D.F., Mexico, 2010.

55. Navarro, E. Fundamentos de la Investigación y la Innovación Educativa; Universidad Internacional de La Rioja: Logroño, Spain, 2017.

56. Kolmos, A.; Hadgraft, R.G.; Holgaard, J.E. Response strategies for curriculum change in engineering. Int. J. Technol. Des. Educ. 2016, 26, 391-411. [CrossRef]

57. Trujillo, F. Aprendizaje Basado en Proyectos; Ministerio de Educación, Cultura y Deporte: Madrid, Spain, 2015.

58. Rosenthal, R. Meta-Analytic Procedures for Social Research, 2nd ed.; SAGE: Newbury Park, CA, USA, 1991.

59. Cohen, J. Statistical Power Analysis for the Behavioral Sciences, 2nd ed.; Lawrence Erlbaum: Hillsdale, NJ, USA, 1988.

60. Maldonado, M. Aprendizaje basado en proyectos colaborativos. Una experiencia en educación superior. Laurus Revista de Educación 2008, 14, 158-180.

61. Chávez, F.H.; Cantú, M.; Rodríguez, C.M. Competencias digitales y tratamiento de información desde la mirada infantil. Rev. Electrón. Investig. Educ. 2016, 18, 209-220. 
62. Rivera, V. Educar para la solidaridad mediante el aprendizaje basado en proyectos: Enamóra+e. In Congreso Iberoamericano de Ciencias, Tecnología, Innovación y Educación; Asenjo, J., Toscano, J.C., Eds.; OEI para la Educación, la Ciencia y la Cultura: Buenos Aires, Argentina, 2015; pp. 1-20.

63. Cascales, A.; Carrillo, M.E. Aprendizaje basado en proyectos en Educación Infantil: Cambio pedagógico y social. Rev. Iberoam. Educ. 2018, 76, 79-98.

64. Remacha, I.; Belletich, O. El método de aprendizaje basado en proyectos (ABP) en contextos educativos rurales y socialmente desfavorecidos de la Educación Infantil. Perspectiva Educacional Formación de Profesores 2015, 54, 90-109.

65. Ortí, J.A.; Iniesta-Sepúlveda, M. Didáctica de la Matemática a través de la Música y el Aprendizaje por Proyectos en Educación Infantil. Rev. Int. De Educ. Preesc. E Infant. 2016, 2, 31-40.

66. Cascales, A.; Carrillo, M.E.; Redondo, A.M. ABP y Tecnología en Educación Infantil. Píxel-Bit Rev. Medios Educ. 2017, 50, 201-209.

67. García-Varcálcel, A.; Gómez-Pablos, V.B. Aprendizaje basado en proyectos (ABP): Evaluación desde la perspectiva de alumnos de Educación Primaria. Rev. Investig. Educ. 2017, 35, 113-131.

68. Dong, C.; Newman, L. Ready, steady ... pause: Integrating ICT into Shanghai preschools. Int. J. Early Years Educ. 2016, 24, 224-237. [CrossRef]

69. Segall, A.; Gaudelli, W. Reflecting Socially on Social Issues in a Social Studies Methods Course. Teach. Educ. 2007, 18, 77-92. [CrossRef]

70. Pagès, J. La educación política y la enseñanza de la actualidad en una sociedad democrática. Educ. Foco 2015, 19, 17-37.

71. Santisteban, A. Cómo trabajar en clase la competencia social y ciudadana. Aula Innov. Educ. 2009, 187, 12-15.

72. Habók, A.; Nagy, J. In-service teachers' perceptions of project-based learning. SpringerPlus 2016, 5. [CrossRef]

73. Farnsworth, C. Using computer simulations in problem-based learning. In Proceedings of the Thirty-Fifth ADCIS Conference, Nashville, TN, USA, 15-19 February 1994; Orey, M., Ed.; Omni Press: Nashville, TN, USA, 1994; pp. 137-140.

74. Wang, W.; Schmidt-Crawford, D.; Jin, Y. Preservice Teachers' TPACK Development: A Review of Literature. J. Digit. Learn. Teach. Educ. 2018, 34, 234-258. [CrossRef] 